\title{
PENGARUH CASH TURNOVER, INVENTORY TURNOVER, DEBT TO EQUITY DAN WORKING CAPITAL TOTAL ASSET RATIO TERHADAP RETURN ON ASSET (ROA) PADA SAUDIA TOSERBA COMAL
}

\author{
Rizka Ariyanti, Jilma Dewi A, M. Zain \\ Politeknik pusmanu, Jl. Jendral Sudirman 29, Pekalongan, Jawa Tengah \\ rizkaariyanti81@gmail.com
}

\begin{abstract}
This study aims to determine the influence return on assets consists of cash turnover, inventory turnover, debt to equity and working capital to total assets ratio. This research was conducted on Arabia Comal Department Store in 2016-2018 with the object of research is the Shop Saudi Toserba in Comal uses the method of multiple linear regression analysis. Based on the results of the partial cash turnover test it has no effect significant, inventory turnover has a significant negative effect, debt to equity does not have a significant effect and working capital to total assets ratio has a significant effect on return on assets in stores Saudi Comal Department Store. Simultaneous cash turnover, inventory turnover, debt to equity and working capital to asset ratio significantly influence return on assets. The adjusted $R$ square value is $49.10 \%$ which means that variable cash turnover, inventory turnover, and sales growth are able explained 49,10\% of the causes of variations or changes which occurred on return on assets while the remaining $50.90 \%$ influenced by other variables not included in this study.
\end{abstract}

Keywords: Cash Turnover, Inventory turnover, Debt To Equity, Working capital, $R O A$.

\begin{abstract}
ABSTRAK:Penelitian ini bertujuan untuk mengetahui yang mempengaruhi return on asset terdiri dari cash turnover, inventory turnover, debt to equity dan working capital to total assets ratio. Penelitian ini dilakukan pada Saudi Toserba Comal pada tahun 2016-2018 dengan objek penelitian adalah Toko Saudi Toserba di Comal menggunakan metode analisa regresi linear berganda. Berdasarkan hasil uji parsial cash turnover tidak memiliki pengaruh yang signifikan, inventory turnover berpengaruh negatif signifikan, debt to equity tidak memiliki pengaruh yang signifikan dan working capital to total assets ratio memiliki pengaruh secara signifikan terhadap return on asset pada toko Saudi Toserba Comal. secara simultan cash turnover, inventory turnover, debt to equity dan working capital to asset ratio berpengaruh signifikan terhadap return on asset. Nilai adjusted $\mathrm{R}$ square sebesar $49,10 \%$ yang berarti bahwa variabel cash turnover, inventory turnover, dan sales growth mampu menjelaskan sebesar $49,10 \%$ penyebab terjadinya variasi atau perubahan yang terjadi pada return on asset sedangkan sisanya sebesar 50,90\% dipengaruhi oleh variabel lain yang tidak dimasukkan dalam penelitian ini.
\end{abstract}

Kata Kunci: Cash Turnover, Inventory turnover, Debt To Equity, Working capital, $R O A$. 


\section{PENDAHULUAN}

Dalam era industrialisasi yang semakin kompetitif sekarang ini, persaingan yang semakin meningkat baik di pasar domestik maupun di pasar internasional menuntut perusahaan untuk dapat mempertahankan atau memperoleh keuntungan kompetitif dengan cara memberikan perhatian penuh pada kegiatan operasional dan finansial perusahaan.

Penelitian Lili Syafitri (2015) meneliti pengaruh inventory turnover Dan total asset turnover terhadap profitabilitas pada CV. Teluk Kenanga Ogan Ilir secara simultan inventory turnover dan total asset turnover mempunyai pengaruh yang signifikan terhadap profitabilitas. Marlina Widiyanti dan Bakar W. Samadi (2014) yang meneliti pengaruh working capital turnover, cash turnover, inventory turnover, dan current ratio terhadap return on asset (ROA) perusahaan property dan real estate yang terdaftar di BEI hasilnya menunjukkan bahwa working capital turnover tidak memiliki pengaruh terhadap profitabilitas (ROA), cash turnover memberikan positif dan pengaruh signifikan terhadap profitabilitas (ROA), inventory turnover memberikan hasil positif dan pengaruh signifikan terhadap profitabilitas (ROA), dan current ratio tidak memiliki pengaruh terhadap Profitabilitas (ROA). Secara bersamaan, working capital turnover, cash turnover, inventory turnover, dan current ratio memiliki pengaruh terhadap profitabilitas (ROA) dengan persentase kontribusi $45,1 \%$. Dapat disimpulkan $\quad 45,1 \% \quad$ variabel independen memiliki pengaruh untuk variabel dependen.

Pitoyo M. Merianti dan Lestari H. Setyo (2018) meneliti pengaruh likuiditas terhadap profitabilitas perusahaan manufaktur yang terdaftar di BEI hasilnya rasio super cepat / rasio kas memiliki pengaruh negatif signifikan terhadap profitabilitas return on asset (ROA) dan rasio perputaran persediaan memiliki pengaruh negatif signifikan terhadap profitabilitas return on capital (ROCE) wiraswasta, sedangkan rasio lancar, rasio cepat, rasio super cepat, rasio perputaran aset saat ini, rasio perputaran persediaan, dan periode pengumpulan rata-rata tidak berpengaruh pada profitabilitas pengembalian aset (ROA), laba atas ekuitas (ROE), laba pada modal dan wiraswasta (ROCE). Andy Kridasusila dan Windasari Rachmawati (2016) meneliti pengaruh current ratio, inventory turnover dan debt to equity ratio pada perusahaan otomotif dan produk komponennya yang terdaftar di BEI (2010-2013) Hasilnya current ratio, inventory turnover dan debt to equity ratio memiliki pengaruh yang signifikan terhadap return on asset (ROA).

Berdasarkan ketidak konsistenan hasil dari penelitian terdahalu yang telah diuraikan diatas, maka penelitian ini ingin meneliti kembali faktor-faktor yang mempengaruhi profitabilitas Return On Asset (ROA).

\section{Rumusan Masalah :}

Rumusan masalah dalam penelitian ini yaitu Faktor apa sajakah yang mempengaruhi ROA . Adapun pertanyaan penelitian (research questions) yang diajukan dalam penelitian ini adalah sebagai berikut:

1.Apakah Inventory Turnover berpengaruh terhadap Return On Asset (ROA)?

2.Apakah Cash Turnover berpengaruh terhadap Return On Asset (ROA)?

3.Apakah Debt To Equity berpengaruh terhadap Return On Asset (ROA)?

4.Apakah Working Capital To Total Assets Ratio berpengaruh terhadap Return On Asset (ROA)?

5. Apakah Cash Turover, Inventory Turnover, Debt To Equity dan 
Working Capital To Total Assets Ratio berpengaruh secara simultan (bersama-sama) terhadap Return On Asset (ROA)?

\section{Return On Asset (ROA)}

Return On Asset (ROA) merupakan salah satu rasio profitabilitas yang dapat mengukur kemampuan perusahaan dalam menghasilkan laba dari asset yang digunakan. ROA mampu mengukur kemampuan perusahaan menghasilkan keuntungan pada masa lampau untuk kemudian diproyeksikan di masa yang akan datang.

Assets atau asset yang dimaksud adalah keseluruhan harta perusahaan, yang diperoleh dari modal sendiri maupun dari modal asing yang telah diubah perusahaan menjadi asset-asset perusahaan yang digunakan untuk kelangsungan hidup perusahaan. Return On Asset dipakai untuk mengevaluasi apakah manajemen telah mendapat imbalan yang memadai (reasobable return) dari aset yang dikuasainya. Rasio ini merupakan ukuran yang berfaedah jika seseorang ingin mengevaluasi seberapa baik perusahaan telah memakai dananya. Oleh karena itu, Return On Asset kerap kali dipakai oleh manajemen puncak untuk mengevaluasi unit-unit bisnis di dalam suatu perusahaan multinasional (Hery Simamora, 2000:530).

\section{Cash Turnover (CTO)}

Dengan menghitung tingkat perputaran kas akan diketahui sampai berapa jauh tingkat efisiensi yang dapat dicapai perusahaan dalam upaya mendayagunakan persediaan kas yang ada untuk mewujudkan tujuan perusahaan. Menurut Kasmir (2013:140) menyatakan rasio perputaran kas (cash turnover) berfungsi untuk mengukur tingkat kecukupuan modal kerja perusahaan yang dibutuhkan untuk membayar tagihan dan membiayai penjualan. Artinya rasio ini digunakan untuk mengukur tingkat ketersediaan kas untuk membayar tagihan (utang) dan biaya-biaya yang berkaitan dengan penjualan.

Penelitian yang dilakukan oleh Veda Almira (2014) mengungkapkan bahwa cash turnover memiliki hubungan yang positif signifikan terhadap profitabilitas.

\section{Debt To Equity ratio}

Bambang Riyanto (2011:49) menyatakan Debt to Equity Ratio atau dalam bahasa Indonesia disebut dengan Rasio Hutang terhadap Ekuitas atau Rasio Hutang Modal adalah beberapa bagian dari keseluruhan aset yang dibelanjai dengan utang. Menurut Rasio Debt to Equity ini juga dikenal sebagai Rasio Leverage (rasio pengungkit) yaitu rasio yang digunakan untuk mengukur seberapa baik struktur investasi suatu perusahaan. (Wild, Subramanyam, dan Halsey, 2005:38).

Debt to Equity Ratio atau DER adalah rasio keuangan utama dan digunakan untuk menilai posisi keuangan suatu perusahaan. Rasio ini juga merupakan ukuran kemampuan perusahaan untuk melunasi kewajibannya. Rasio Debt to Equity ini merupakan rasio penting untuk diperhatikan pada saat memeriksa kesehatan keuangan perusahaan. Jika rasionya meningkat, ini artinya perusahaan dibiayai oleh kreditor (pemberi hutang) dan bukan dari sumber keuangannya sendiri yang mungkin merupakan trend yang cukup berbahaya. Pemberi pinjaman dan Investor biasanya memilih Debt to Equity Ratio yang rendah karena kepentingan mereka lebih terlindungi jika terjadi penurunan bisnis pada perusahaan yang bersangkutan. Dengan demikian, perusahaan yang memiliki Debt to Equity Ratio atau Rasio Hutang terhadap Ekuitas yang tinggi mungkin tidak dapat menarik tambahan modal dengan pinjaman dari pihak lain. 


\section{Working Capital To Total Assets Ratio (WCTAR)}

Working capital to total assets ratio (WCTA ratio) adalah likuiditas dari total aktiva dan posisi modal kerja. Modal kerja yang dimaksud disini adalah modal kerja neto, yaitu sebagian dari aktiva lancar yang benar-benar dapat digunakan untuk membiayai operasinya perusahaan tanpa mengganggu likuiditasnya (Bambang Riyanto, 2008).

Pada penelitian yang dilakukan oleh Widiyanti, Marlina dan Bakar W. Samadi (2014) mengungkapkan bahwa inventory turnover secara silmutan memiliki hubungan yang positif signifikan terhadap profitabilitas

Berdasarkan kajian teori yang sudah dikemukakan diatas, maka kerangka pemikiran dalam penelitian ini adalah sebagai berikut:

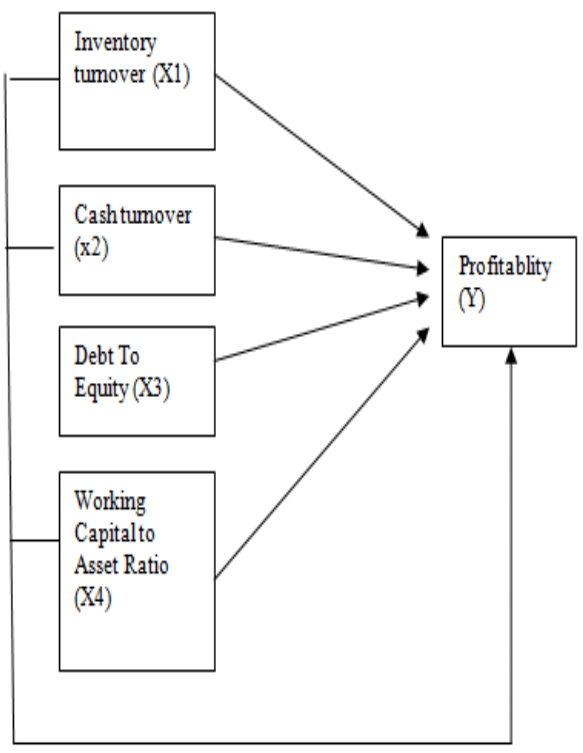

\section{Gambar1: Kerangka Berpikir}

\section{METODE}

Variabel penelitian adalah segala sesuatu yang berbentuk apa saja yang ditetapkan oleh peneliti untuk dipelajari sehingga diperoleh informasi tentang hal tersebut, kemudian ditarik kesimpulan (Sugiyono, 2013: 38). Variabel yang digunakan dalam penelitian dapat diklasifikasikan menjadi: variabel independen (bebas), yaitu variabel yang menjelaskan dan memengaruhi variabel lain, dan (2) variabel dependen (terikat), yaitu variabel yang dijelaskan dan dipengaruhi oleh variabel independen.

1.Variabel Independen

Variabel independen adalah variabel yang sering disebut sebagai variabel stimulus, prediktor, dan antesenden. Dalam bahasa Indonesia sering disebut sebagai variabel bebas. Variabel ini memengaruhi atau yang menjadi sebab perubahannya atau timbulnya variabel dependen (Sugiyono, 2013: 39). Variabel independen dalam penelitian ini adalah cash turnover (X1), inventory turnover (X2), debt to equity (X3) dan working capital to total assets ratio $(\mathrm{X} 4)$.

\section{Variabel Dependen}

Variabel dependen sering disebut sebagai variabel output, kriteria, dan konsekuen. Dalam bahasa Indonesia sering disebut sebagai variabel terikat. Variabel terikat merupakan variabel yang dipengaruhi atau yang menjadi akibat, karena adanya variabel bebas (Sugiyono, 2013: 39). Variabel dependen dalam penelitian ini adalah profitability (return on asset) sebagai $\mathrm{Y}$.

\section{Analisis Regresi Linear Berganda}

Analisis regresi merupakan suatu metode atau teknik analisis hipotesis penelitian untuk menguji ada tidaknya pengaruh antara variabel satu dengan variabel lain yang dinyatakan dalam bentuk persamaan matematik (regresi). Analisis regresi linier multiples atau berganda berfungsi untuk mencari pengaruh dari dua atau lebih variabel independen (variabel bebas atau X) terhadap variabel dependen (variabel terikat atau Y).

Rumus persamaan analisis regresi berganda: $\mathrm{Y}=\mathrm{a}+\mathrm{b} 1 \mathrm{x} 1+\mathrm{b} 2 \mathrm{x} 2 \quad \mathrm{bn}$ 
HASIL DAN PEMBAHASAN Analisis Regresi Linear Berganda Analisis regresi linear berganda dipakai untuk mengetahui besarnya pengaruh variabel independen terhadap variabel dependen. Berikut hasil output uji regresi

Tabel 1 Hasil Uji Analisis Linier Berganda

\begin{tabular}{|c|c|c|c|c|c|c|c|}
\hline \multirow[t]{2}{*}{ Model } & \multicolumn{2}{|c|}{$\begin{array}{l}\text { Unstandardized } \\
\text { Coefficients }\end{array}$} & \multirow{2}{*}{$\begin{array}{c}\begin{array}{c}\text { Standardized } \\
\text { Coefficients }\end{array} \\
\text { Beta }\end{array}$} & \multirow[t]{2}{*}{$\mathrm{t}$} & \multirow[t]{2}{*}{ Sig } & \multicolumn{2}{|c|}{$\begin{array}{c}\text { Collinearity } \\
\text { Statistics }\end{array}$} \\
\hline & $\mathrm{B}$ & $\begin{array}{l}\text { Std. } \\
\text { Error }\end{array}$ & & & & Tolerance & VIF \\
\hline (Constant) & .076 & .018 & & 4.211 & .000 & & \\
\hline CTO & $\begin{array}{r}9.835 \mathrm{E}^{-} \\
6 \\
\end{array}$ & .000 & -.055 & -.111 & .913 & .089 & 9.226 \\
\hline ITO & .000 & .000 & -.789 & -2.324 & 031 & . 192 & 5.209 \\
\hline DTE & .000 & .003 & .022 & .068 & .947 & .202 & 4.957 \\
\hline WCTAR & 032 & .011 & .479 & 2.851 & .010 & .782 & 1.279 \\
\hline
\end{tabular}

a. Dependent Variable: ROA

Sumber: Data diolah menggunakan SPSS versi 16 (2007).

Dari uji regresi linear berganda maka diperoleh persamaan matematis: $\mathrm{Y}=$ $0,076-9,835 \mathrm{X} 1+0 \mathrm{X} 2+0 \mathrm{X} 3+0,032 \mathrm{X} 4$ $+\mathrm{e}$

a. Nilai konstanta sebesar 0,076 menyatakan jika cash turnover (X1), inventory turnover (X2), Debt To Equity (X3) dan Working Capital To Total Ratio (X4) bernilai 0, maka return on assets nilainya adalah 0,076 .

b. Nilai cash turnover (X1) sebesar 9,835, karena negatif menyatakan setiap penambahan $1 \%$ cash turnover maka return on assets akan menurun sebesar $-9,835$.

c. Nilai inventory turnover (X2) sebesar 0, karena positif menyatakan setiap penambahan $1 \%$ inventory turnover, maka return on assets akan meningkat sebesar 0,076 .

d. Nilai debt to equity (X3) sebesar 0, karena positif menyatakan setiap penambahan $1 \%$ debt to equity, maka return on assets akan meningkat sebesar 0,076 .

e. Nilai working capital to total ratio (X4) sebesar 0,032, karena positif menyatakan setiap penambahan $1 \%$ working capital to total ratio, maka return on assets akan meningkat sebesar 0,032 .

\section{Koefisien Determinasi (Uji R2)}

Pengujian ini bertujuan melihat berapa besar kemampuan model dalam menerangkan variasi variabel dependen. Nilai R2 adalah antara nol sampai satu. Jika nilainya mendekati 1 maka hubungannya semakin erat, tetapi jika mendekati 0 maka hubungannya semakin lemah. Hasil output pengolahan data adalah berikut ini:

Tabel 2 Hasil Uji Koefisian Determinasi (R2)

\begin{tabular}{rrrrr}
\hline Model & $\mathrm{R}$ & $\begin{array}{l}\mathrm{R} \\
\text { Squ } \\
\text { are }\end{array}$ & $\begin{array}{l}\text { Adjusted } \\
\text { R Square }\end{array}$ & $\begin{array}{l}\text { Std. Error } \\
\text { of the } \\
\text { Estimate }\end{array}$ \\
\hline & $.762^{\mathrm{a}}$ & .580 & .491 & .007 \\
\hline
\end{tabular}

a. Predictors: (Constant), WCTAR, ITO, DTE, CTO

b. Dependent Variable: ROA

Berdasarkan nilai koefisien determinasi diperoleh nilai $\mathrm{R}$ sebesar 0,607 dan Adjusted $R$ Square sebesar 0,491 atau $49,10 \%$ yang berarti semua variabel independen mampu menjelaskan sebesar $49,10 \%$ penyebab terjadinya variasi yang terjadi pada return on assets 
sedangkan sisanya sebesar $50,90 \%$ dipengaruhi oleh variabel lain yang tidak termasuk dalam penelitian ini.

a.Variabel cash turnover mempunyai hubungan yang negatif terhadap return on assets dan memiliki hubungan yang tidak signifikan terhadap return on assets dimana tingkat hubungan yang dimiliki rendah. Hal ini sesuai dengan hasil analisis yang menyatakan bahwa cash turnover hubungan yang negatif terhadap return on assets. Koefisien bertanda negatif membuktikan bahwa cash turnover mengalami peningkatan maka return on assets akan mengalami penurunan, dan sebaliknya. Hasil penelitian ini tidak sejalan dengan penelitian Veda Almira (2014) dan Andy Kridasusila dan Windasari Rachmawati (2016) yang mengungkapkan bahwa cash turnover memiliki pengaruh yang signifikan terhadap return on assets. Namun penelitian ini sejalan dengan penelitian Ellyn Octavianty (2013) bahwa cash turnover tidak memiliki pengaruh yang signifikan.

b.Variabel inventory turnover mempunyai hubungan yang negatif terhadap return on assets dan memiliki hubungan yang signifikan terhadap return on assets. Hal ini sesuai dengan hasil analisis yang menyatakan bahwa inventory turnover hubungan yang negatif terhadap return on assets. Koefisien bertanda negatif membuktikan bahwa inventory turnover mengalami peningkatan maka return on assets akan mengalami penurunan, dan sebaliknya. Hasil penelitian ini sejalan dengan penelitian Marlina Widiyanti dan Bakar W. Samadi (2014), Lili Syafitri (2015) dan Andy Kridasusila dan Windasari Rachmawati (2016) yang mengungkapkan bahwa inventory turnover memiliki pengaruh yang signifikan terhadap return on assets.

c. Variabel debt to equity mempunyai hubungan yang positif terhadap return on assets dan memiliki hubungan yang tidak signifikan terhadap return on assets. Hal ini sesuai dengan hasil analisis yang menyatakan bahwa debt to equity hubungan yang positif terhadap return on assets. Koefisien bertanda positif menunjukan debt to equity berbanding lurus dengan return on assets. Yang berarti bahwa debt to equity mengalami peningkatan maka return on assets akan mengalami peningkatan juga, dan sebaliknya. Hasil penelitian ini tidak sejalan dengan penelitian Andy Kridasusila dan Windasari Rachmawati (2016) yang mengungkapkan bahwa debt to equity memiliki pengaruh yang signifikan terhadap return on assets. Namun secara silmutan debt to equity memiliki pengaruh yang signifikan terhadap return on assets.

d. Variabel working capital to total assets ratio mempunyai hubungan yang positif terhadap return on assets dan memiliki hubungan yang signifikan terhadap return on assets. Hal ini sesuai dengan hasil analisis yang menyatakan bahwa working capital to total assets ratio hubungan yang positif terhadap return on assets. Koefisien bertanda positif menunjukan working capital to total assets ratio berbanding lurus dengan return on assets. Yang berarti bahwa working capital to total assets ratio mengalami peningkatan maka return on assets akan mengalami peningkatan juga, dan sebaliknya. Hasil penelitian ini sejalan dengan penelitian Marlina Widiyanti dan Bakar W. Samadi (2014) yang mengungkapkan bahwa working capital to total assets ratio secara silmutan memiliki pengaruh yang signifikan terhadap return on assets. Namun dalam uji $t$ tidak sejalan karena pada penelitiannya working capital to total assets ratio tidak berpengaruh terhadap return on assets.

e. Variabel Cash turnover, inventory turnover, debt to equity dan working capital to asset ratio secara bersama- 
sama atau silmutan berpengaruh signifikan terhadap return on assets. Hasil Penelitian ini sejalan dengan penelitian yang dilakukan oleh peneliti-peneliti terdahulu secara silmutan memiliki pengaruh yang signifikan terhadap profitabilitas.

\section{DAFTAR PUSTAKA}

Almira V. 2014. Pengaruh Inventory Turnover, Receivable Turnover, Working Capital Turnover, Cash Turnover dan Sales Growth Terhadap Net Profit Margin Ratio Pada Perusahaan Manufaktur Aneka Industri yang Terdaftar di Bursa Efek Indonesia Periode 2011-2013. Jurnal Universitas Maritim Raja Ali Haji.

Ambarwati S, D, A. 2010. Manajemen Keuangan Lanjut. Yogyakarta : Graha Ilmu.

.Aris Triyono. 2018. Analisis Pengaruh Kontribusi Pajak Reklame dan Pajak Hiburan Terhadap Pendapatan Asli Daerah (PAD) Pada Badan Pendapatan Daerah Kabupaten Indragiri Hulu. Sekolah Tinggi Ilmu Ekonomi Indragiri Rengat

Brigham F. Eugene dan Houston, Joel. 2010. Dasar-Dasar Manajemen K3euangan. Edisi Kesebelas. Jakarta : Salemba Empat.

Gunawan, Imam. 2016. Metode Penelitian Kualitatif. Jakarta : Bumi Aksara

Hantono. 2017. Konsep Analisa Laporan Keuangan dengan Pendekatan Rasio dan SPSS. Jogjakarta : Deepublish.

Hery. 2012. Analisis Laporan Keuangan. Jakarta : PT. Bumi Aksara.

Ikhsan A. 2009. Pengantar Praktis
Akuntansi. Yogyakarta : Graha Ilmu.

Jumingan. 2005. Analisis Laporan Keuangan. Jakarta : Bumi Aksara.

Kasmir. 2013. Analisi Laporan Keuangan. Edisi. Ke-empat. Cetakan Ketiga Belas. Yogyakarta: Liberty

Kridasusila, Andy dan Rachmawati, Windasari. 2016. Pengaruh Current Ratio, Inventory Turnover Dan Debt to Equity Ratio Pada Perusahaan Otomotif Dan Produk Komponennya Yang Terdaftar Di Bursa Efek Indonesia (2010-2013). Jurnal Dinamika Sosial Budaya.

Munawir. 2014. Analisa Laporan Keuangan. Yogyakarta: Liberty

Octavianty, Ellyn. 2013. Analisis Pengaruh Likuiditas Terhadap Profitabilitas Pada Perusahaan Dagang Yang Terdaftar di BEI (2008-2012). Jurnal Universitas Pakuan.

Pitoyo M. Merianti dan Lestari H. Setyo. 2018. Pengaruh Likuiditas Terhadap Profitabilitas Perusahaan Manufaktur Yang Terdaftar di Bursa Efek Indonesia. Jurnal Universitas Trisakti Jakarta.

Politeknik Pusmanu. 2019. Buku Panduan Praktek Kerja Lapangan dan Penulisan Tugas Akhir. Pekalongan.

Riyanto, Bambang. 2011. Dasar-Dasar Pembelanjaan Perusahaan. Edisi Ke empat. Yogyakarta: BPFE.

Salim, Emil. 2002. Akuntansi intermediate jilid 1 / Donald E. Kieso, Jerry J. Weygandt, Terry D. Warfield ; alih bahasa Emil Salim. Jakarta: Erlangga 